\title{
Free-range grazing by large herbivores in degraded large-scale dry sandy grassland-heathland ecosystems
}

\author{
René Seifert, Antje Lorenz, Susanne Osterloh, Katrin Henning, Sabine Tischew \\ Anhalt University of Applied Sciences, Department for Nature Conservation and Landscape Planning, \\ D-06406 Bernburg, Germany, \\ email: r.seifert@loel.hs-anhalt.de
}

\begin{abstract}
Free-range grazing by large herbivores combined with one-time mowing of over-aged heathlands offers an excellent management tool to maintain and enhance biodiversity in degraded large scale, low productive, semi-open dry sandy grassland-heathland ecosystems. Grazing improves habitat quality, supports typical species communities and represses invasive species.
\end{abstract}

Key words:year-round grazing, cattle / horses, habitat quality, foraging behaviour, Prunus serotina.

\section{Introduction and study area}

Land-use abandonment in low-productive, but large scale dry sandy grassland-heathland ecosystems is a major problem throughout Europe, causing a rapid grass and tree encroachment, favouring invasive species and consequently threatening the typical species diversity of these NATURA 2000 habitats (e. g. Bakker et al., 2012). To counteract these trends and to improve the habitat quality, a new management tool using free-range grazing by large herbivores (Heck cattle and Konic horses) combined with one-time mowing of over-aged heathlands was tested on a 800 ha pasture with long-term abandoned grassland and heathland habitats in the Eastern part of Germany (N51 ${ }^{\circ} 46^{\prime} 22.246^{\prime \prime}$, E12 21 '34.448”). The advanced shrub and tree encroachment was drastically reduced by cutting before the grazing management was implemented. This study gives an overview on effects of the grazing management on vegetation structure, plant species composition, soil parameters, the invasive native grass species Calamagrostis epigeios and invasive tree species Prunus serotina, habitat typical bird species and on large herbivores behaviour patterns.

\section{Methods}

Grazing effects were evaluated by using before / after and with / without approaches on different spatial scales (Lorenz et al., 2013). Since 2008 the habitat quality parameters (grasses, litter and bare soil) were investigated on 43 macroplots $(100 \mathrm{~m} \times 100 \mathrm{~m})$ of grassland and heathland habitats. Trajectories on plant community scale were analysed on microplots $(5 \mathrm{~m}$ x $5 \mathrm{~m})$ in the centre of each macroplot up to 2013. Soil samples were collected in 2009 and 2013. Total nitrogen contents were determined by running an elemental analysis using the CNS-Analyser 2000 (LECO Instruments, DIN ISO 13878). The non-parametric Wilcoxon test was used to test for differences. Foraging behaviour of large grazers was quantified by direct animal observations. Habitat preferences for over-aged and mown heath were determined using the Ivlev`s Electivity Index (Jakobs, 1974). Regrowing shoots of the invasive tree species Prunus serotina were surveyed (counts of browsed / unbrowsed, annual growth, mortality) for six years until 2014. The non-parametric Mann-Whitney-U-Test was used to test for differences. Breeding territories of target bird species like Lullula arborea and Camprimulgus europaeus 


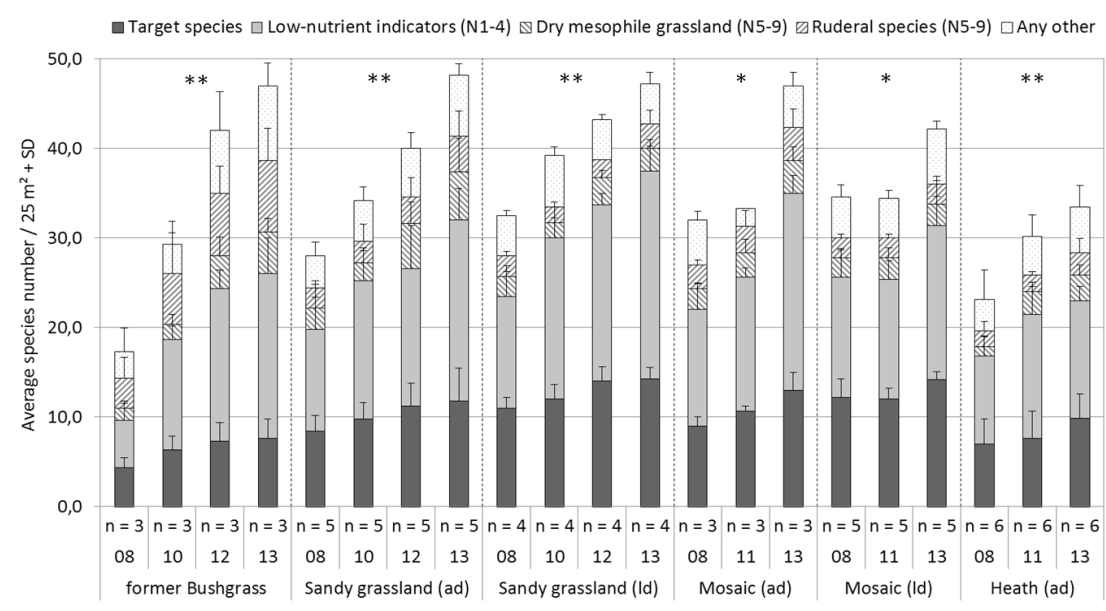

Figure 1. Development of average species numbers regarding ecological species groups in grazed bushgrass stands (Calamagrostis epigejos), dry sandy grasslands, dry heath communities and grassland/heath mosaics from 2008 to 2013. Repeated-measures ANOVA was calculated to test for differences over time regarding the total species number within vegetation units. Degradation status: (ad) $=$ advanced, $(\mathrm{ld})=$ low. Asterisks mark significance levels: $* * * \mathrm{p} \leq 0.001, * *$ $0.01 \geq \mathrm{p}>0.001, * 0.05 \geq \mathrm{p}>0.01$, n. s. $\mathrm{p} \geq 0.05$

were mapped in 2005, before the management was implemented, as well as in 2009 and 2012.

\section{Results}

Large grazers improved habitat quality rapidly within the first four years, indicated by a decreased coverage of the invasive native grass species Calamagrostis epigejos, litter coverage and thickness but an increased percentage of bare soil in most of the habitats. Hence, plant species diversity increased remarkably: in former bushgrass stands from 18 to 48 species / $25 \mathrm{~m}^{2}$, in dry sandy grasslands from 28 to 48 and in heath stands from 23 to 34 due to the immigration of species typical for nutrient-poor site conditions (Fig. 1).

The total soil nitrogen content of all sites has been maintained at a low level $(<0.26 \%)$ or even decreased significantly in heathland $(\mathrm{p}=0.039)$ and dry grassland / heathland mosaic plots $(p=0.030)$. Cattle and horses generally preferred grassland dominated habitats compared to heathlands. Particularly cattle preferred mown heath compared to only grazed ones and browsed more frequently on Prunus serotina than horses with up to $3 \%$ of their daily intake. Studies on regrowing shoots of Prunus serotina indicated a high browsing efficiency of $89 \%$ up to $98 \%$ for the first years of management (2009 to 2011). As in the years before, in 2014 a shorter average shoot length (31.2 $\mathrm{cm} \pm 32.1 \mathrm{SD}, \mathrm{n}=59)$ compared to ungrazed shoots $(125.4 \mathrm{~cm} \pm 27.4 \mathrm{SD}, \mathrm{n}=17)$ has been measured $(\mathrm{p}=0.000)$. Furthermore a mortality of individuals with
$58 \%$ after six years of grazing has been observed. The management measures positively affected the number of breeding pairs of woodlark (Lullula arborea) and nightsjar (Camprimulgus europaeus), which increased from 37 to 45 and from 42 to 72, respectively (ÖKO \& PLAN, 2013).

\section{Discussion}

Extensive free-range grazing by large herbivores in abandoned low-productive dry grassland-heathland habitats improves vegetation structure by reducing biomass, particularly in C. epigejos dominated stands, as well as litter layer and vegetation height (see also e. g. Schwabe et al. 2013). Consequently, species richness can be supported by grazing, especially if target species are still present as it was in our case (Bakker \& Berendse, 1999; Bokdam \& Gleichnam, 2000; Schwabe et al., 2013). Grazing seems to be suitable to maintain a low soil nitrogen status in regions with low atmospheric nitrogen deposition rates like our study area. In contrast, additional management measures are necessary in sites with high nitrogen deposition rates (Härdtle et al., 2006). To counteract the regrowth of cutted Prunus serotina individuals cattle browsing on young shoots and leaves seem to be suitable (see also Vanhellemont, 2009). Only in large Prunus serotina occurrences, additional measures are indispensable. Concluding, freerange large herbivore grazing with Heck cattle and Kon$\mathrm{ik}$ horses is an effective management tool to restore and maintain dry sandy grasslands and heathlands. 


\section{References}

Bakker J.P., Berendse F., 1999, Constraints in the restoration of ecological diversity in grassland and heathland communities, Tree, 14: 63-68.

Bakker J.P., Van Diggelen R., Bekker R.M. \& Marrs R.H., 2012, Restoration of Dry Grasslands and Heathlands, [in:] J. van Andel, J. Aronson (eds) Restoration Ecology: The New Frontier, Blackwell Publishing: 173-188.

Bokdam J., Gleichnam J.M., 2000, Effects of grazing by free-ranging cattle on vegetation dynamics in a continental north-west European heathland, Journal of Applied Ecology, 37: 415-431.

Härdtle W., Niemeyer M., Niemeyer T., Assmann T. \& Fottner S., 2006, Can management compensate for atmospheric nutrient deposition in heathland ecosystems?, Journal of Applied Ecology, 43: 759-769.

Jakobs J., 1974, Quantitative Measurement of Food Selection, A Modification of the Forage Ratio and Ivlev`s Electivity Index, Oecologia, 14: 413-417.
Lorenz A., Tischew S., Osterloh S., Felinks B., 2013, Konzept für maßnahmenbegleitende naturschutzfachliche Erfolgskontrollen in großen Projektgebieten, Naturschutz und Landschaftsplanung 45: 365-372.

ÖKO \& PLAN, 2013, Naturschutzfachliche Erfolgskontrolle von Managementmaßnahmen zum Erhalt und zur Entwicklung von FFH-Offenlandlebensraumtypen im NATURA 2000 Gebiet ,Mittlere Oranienbaumer Heide“, Teil Brutvögel. Studie im Auftrag der Hochschule Anhalt, gefördert über ELER Sachsen-Anhalt, Az: 407.1.7-60128/323011000001.

Schwabe A., Süss K. \& Storm C., 2013, What are the longterm effects of livestock grazing in steppic sandy grassland with high conservation value? Results from a 12year field study, Tuexenia, 33: 189-212.

Vanhellemont M., 2009, Present and future population dynamics of Prunus serotina in forests in its introduced range, $\mathrm{PhD}$ thesis, Ghent University, Ghent, Belgium. 